\title{
Pengembangan Media Pembelajaran Matematika Berbasis Android pada Materi Trigonometri
}

Firda Fina Fitriya, Siti Faizah

How to cite : Fina Fitriya, F., \& Siti Faizah. (2021). Pengembangan Media Pembelajaran Matematika Berbasis Android pada Materi Trigonometri. Kognitif: Jurnal Riset HOTS Pendidikan Matematika, 1(2), 104 - $114 .$. https://doi.org/10.51574//kognitif.v1i2.108

To link to this article : https://doi.org/10.51574/kognitif.v1i2.108

Opened Access Article

111 Published Online on 1 Desember 2021

至 Submit your paper to this journal 


\title{
Pengembangan Media Pembelajaran Matematika Berbasis Android pada Materi Trigonometri
}

\author{
Firda Fina Fitriya ${ }^{1}$, Siti Faizah ${ }^{2}$ \\ ${ }^{1,2}$ Program Pendidikan Ilmu Matematika, Universitas Hasyim Asy'ari Jombang
}

\begin{tabular}{l} 
Article Info \\
\hline Article history: \\
Received Sept 28, 2021 \\
Accepted Oct 20, 2021 \\
Published Online Dec 1, 2021 \\
\hline
\end{tabular}

\section{Keywords:}

Pembelajaran Matematika Penelitian Pengembangan Android

Trigonometri

\begin{abstract}
Media pembelajaran matematika berbasis android ini merupakan suatu media pembelajaran matematika dalam bentuk aplikasi pembelajaran. Media pembelajaran ini diharapkan dapat memudahkan siswa dalam belajar matematika di masa pandemic covid 19 saat ini. Penelitian ini bertujuan untuk mengembangkan media pembelajaran matematika berbasis android. Jenis penelitian ini merupakan penelitian pengembangan dengan menggunaan model ADDIE dengan beberapa tahapan yaitu analysys, design, development, implantation, evalution. Hasil penelitian menunjukkan bahwa media pembelajaran matematika berbasis android ini dikategorikan valid dengan rata-rata prsentase skor yaitu 77,94\% dengan presentase rata-rata ahli media yaitu $80,88 \%$ dan presentase rata-rata ahli materi yaitu $75 \%$ sehingga media pembelajaran ini dapat diuji cobakan kepada siswa. Setelah media dinyatakan valid kemudia media yang telah dikembangkan diuji cobakan kepada siswa kemudian siswa mengisi angket respon siswa yang telah disediakan oleh peneliti. Angket respon siswa menunjukkan bawa media ini praktis untuk digunakan siswa dengan prsentase ratarata yaitu $74,63 \%$.
\end{abstract}

This is an open access under the $\underline{C C-B Y-S A}$ licence

All rights reserved

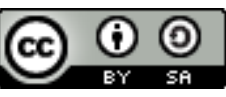

\section{Corresponding Author:}

Siti Faizah,

Pendidikan Matematika,

Universitas Hasyim Asy'ari Jombang

Email: izahfaiz90@gmail.com

\section{Pendahuluan}

Pendidikan merupakan suatu upaya dalam meningkatkan dan mengembangkan kualitas sumber daya manusia secara menyeluruh. Selain itu, pendidikan merupakan suatu proses pengubahan sikap dan tingkah laku seseorang atau sekelompok orang dalam usaha mendewasakan melalui pengajaran dan pelatihan (Nurkholis, 2013). Perkembangan pendidikan seharusnya sejalan dengan proses perkembangan kehidupan agar siswa mampu menghadapi 
dan memecahkan problema kehidupan. Dalam tingkat pendidikan dasar dan menengah, salah satu mata pelajaran yang harus dikuasai oleh siswa adalah matematika.

Menurut (Supardi, 2015) matematika adalah ilmu pengetahuan eksak yang berhubungan dengan logika, penalaran, bilangan, operasi perhitungan, konsep-konsep abstrak, fakta-fakta kuantitatif berupa hubungan pola pikir bentuk dan ruang yang dapat menimbulkan suatu pola pikir yang masuk akal dan berguna untuk mengatasi berbagai macam persoalan dalam kehidupan sehari-hari. Matematika merupakan salah satu cabang ilmu pengetahuan yang penting untuk dipelajari. Meskipun demikian, masih banyak siswa yang kesulitan dalam mempelajari matematika. Sebagaimana pendapat (Auliya, 2016) yang mengatakan bahwa matematika dianggap sebagai pelajaran yang sulit karena karakteristik matematika yang bersifat abstrak, logis, sistematis dan penuh dengan lambang serta rumus yang membingungkan. Penggunaan media pembelajaran merupakan salah satu solusi agar siswa dapat mengurangi tingkat kesulitan dalam mempelajari matematika Kehadiran media pembelajaran dapat menumbuhkan minat siswa dalam belajar matematika, membantu siswa dalam mempelajari serta memahami materi matematika yang masih abstrak (Hamzah B. Uno, 2010). Miarso mengatakan bahwa media pembelajaran adalah segala sesuatu yang digunakan untuk menyalurkan pesan dan dapat merangsang pikiran, perasaan, perhatian dan kemauan sehingga dapat mendorong terjadinya proses belajar yang terstruktur (Nurrita, 2018). Dengan menggunakan media pembelajaran dapat memudahkan guru dalam menjelaskan hal-hal yang bersifat abstak dalam matematika.

Berdasarkan penelitian terdahulu yang relevan, media pembelajaran berbasis android dapat meningkatkan motivasi belajar siswa sehingga pembelajaran menjadi lebih menarik dan menyenangkan serta dapat memberikan pengaruh kepada hasil belajar siswa (Prasetyo et al., 2015). Android juga merupakan suatu sistem operasi untuk perangkat mobile berbasis linux yang mencakup sistem operasi, middleware dan aplikasi (Anggriani et al., 2020). Namun dengan adanya pandemic covid-19 saat ini siswa membutuhkan media pembelajaran jarak jauh yang dapat memudahkan siswa dalam pembelajaran, khususnya pembelajaran matematika. Dengan memanfaatkan perkembangan teknologi saat ini, Salah satu media pembelajaran jarak jauh yang dapat dimanfaatkan dalam dunia pendidikan adalah media pembelajaran berbasis android. Oleh karena itu penelitian ini bertujuan untuk mengembangkan suatu media pembelajaran matematika yang berbasis android yang dapat memudahkan siswa dalam memahami hal-hal abstrak yang sulit difikirkan oleh siswa dalam bentuk media pembelajaran yang berbasis android dan tampilan media pembelajaran dibuat semenarik mungkin agar siswa lebih mudah dalam memahami materi matematika.

\section{Metode}

Penelitian ini merupakan jenis penelitian pengembangan. Penelitian dan pengembangan (Research and Development) adalah suatu metode penelitian yang digunakan untuk menghasilkan suatu produk tertentu dan menguji keefektifan produk tesebut (Sugiyono, 2017). Penelitian pengembangan media pembelajaran berbasis android ini menggunakan model pengembangan ADDIE. Munurut (Pribadi, 2016) Model ADDIE (Analysis, Design, Development, Implentation, Evaluation) dikembangkan oleh Raiser dan Mollenda pada tahun 1990-an. Menurut (Barokati \& Annas, 2013) model ADDIE merupakan salah satu model yang menjadi pedoman dalam mengembangkan suatu pembelajaran yang efektif, dinamis dan mendukung pembelajaran itu sendiri. (Tegeh \& Kirna, 2013) mengatakan bahwa model ADDIE adalah salah satu model desain pembelajaran sistematik dan model ini tersusun secara terprogram dengan urutan-urutan kegiatan yang sistematik dalam upaya pemecahan masalah belajar yang berkaitan dengan sumber belajar sesuai dengan kebutuhan dan karakteristik siswa. Dalam model ADDIE ini terdapat 5 tahapan yaitu analysis, design, development, 
implementation dan evaluation. Penelitian ini bertujuan untuk mengembangkan media pembelajaran matematika berbasis android dan menguji kevalidan dari media tersebut. Instrument pengumpulan data dalam penelitian ini yaitu menggunakan lembar validasi dan angket respon siswa. Dalam penelitian ini terdapat 2 validator yairu satu validastor sebagai ahli media dan satu validator sebagai ahli materi. Berikut teknik analisis yang digunakan dalam penelitian pengembangan ini.

\section{Lembar Validasi}

Dalam lembar validasi terdapat beberapa kolom penilaian yang harus diisi oleh validator. Penilaian dalam lembar validasi tedapat empat tingkatan yaitu sebagai berikut.

Tabel 1 Kategori Rating Scale pada Lembar Validasi

\begin{tabular}{|c|c|}
\hline Skor & Keterangan \\
\hline 4 & Sangat Setuju \\
\hline 3 & Setuju \\
\hline 2 & Cukup Setuju \\
\hline 1 & Tidak Setuju \\
\hline
\end{tabular}

(Suharmi, 2010)

Adapun rumus yang digunakan untuk data lembar validasi sebagai berikut:

$$
\bar{P}=\frac{\sum x}{\sum x_{1}} \times 100 \%
$$

(Zainal Arifin, 2010)

$$
\begin{aligned}
& \text { Keterangan: } \\
& \bar{P}=\text { presentase rata-rata } \\
& \sum x=\text { jumlah total skor } \\
& \sum x_{1}=\text { jumlah skor maksimal }
\end{aligned}
$$

Dari hasil presentase rata-rata kemudian dicocokkan dengan tabel kategori kevalidan media pembelajaran berikut

Tabel 2 Kategori Kevalidan Media Pembelajaran

\begin{tabular}{|c|c|}
\hline $\begin{array}{c}\text { Interval presentase rata- } \\
\text { rata } \\
(\%)\end{array}$ & Kategori Kevalidan \\
\hline $\bar{P} \geq 90$ & Sangat Valid \\
\hline $70 \leq \bar{P}<90$ & Valid \\
\hline $60 \leq \bar{P}<70$ & Cukup Valid \\
\hline $50 \leq \bar{P}<60$ & Kurang Valid \\
\hline $\bar{P}<50$ & Tidak Valid \\
\hline
\end{tabular}

Dalam penelitian ini media pembelajaran matematika berbasis android dikatakan valid apabila telah memenuhi kriteria minimal cukup valid. 


\section{Angket Respon Siswa}

Dalam angket respon siswa ini terdapat beberapa kolom pernyataan. Skor penilaian dalam angket respon siswa ini terdapat beebrapa tingkatan yaitu:

\begin{tabular}{|c|c|}
\hline Skor & Keterangan \\
\hline 4 & Sangat baik \\
\hline 3 & Baik \\
\hline 2 & Cukup baik \\
\hline 1 & Kurang baik \\
\hline
\end{tabular}

Kemudian peneliti menghitung skor tiap butir pernyataan menggunakan rumus berikut:

$$
\mathrm{S}=\frac{A}{B}
$$

Keterangan:

$\mathrm{S}=$ skor

$\mathrm{A}=$ jumlah skor tiap butir

$\mathrm{B}=$ skor maksimal

Setelah skor diketahui kemudian menghitung rata-rata persentase perolehan skor semua putir pernyataan

$$
\bar{S}=\frac{\sum A}{\sum C} \times 100 \%
$$

Keterangan:

$\bar{S}=$ Presentase rata-rata

$\sum A=$ jumlah total skor

$\Sigma C=$ Jumlah aspek penilaian

Angket respon siswa diberikan setelah menggunakan media pembelajaran yang dikembangkan. Respon siswa dikatakan positif terhadap media pembelajaran yang dikembangkan jika persentase rata-rata lebih dari $70 \%$.

\section{Hasil Penelitian}

\section{Tahap Analisis}

Dalam tahap ini peneliti menganalisis kebutuhan belajar dan permasalahan yang dihadapi siswa selama proses pembelajaran. Pada masa pandemic covid 19 saat ini, proses pembelajaran di MA Miftahul ulum dilakukan secara daring dengan menggunakan aplikasi wathsapp sehingga mengakibatkan siswa merasa kurang tertarik dengan pembelajaran karena cendeung pasif. Berdasarkan wawancara terhadap siswa di MA Miftahul ulum mengatakan bahwa $88,2 \%$ siswa mengatakan bahwa siswa membutuhkan media pembelajaran yang interaktif merupa video pembelajaran atau animasi pembelajaran. Dari permasalahan tersebut peneliti mencari solusi dengan media pembelajaran yang dapat menarik minat belajar siswa dan dapat digunakan untuk belajar secara mandiri. Dari hasil analisis permasalahan tersebut, peneliti membuat media pembelajaran berbasis android yang dapat dioperasikan oleh siswa secara offline.

2. Tahap Rancangan 
Pada tahap ini, peneliti membuat rancangan media pembelajaran dengan mengacu dari hasil analisis permasalahan pada tahap sebelumnya. tahap ini dilakukan dengan tiga tahap yaitu perancangan materi, membuat storyboard dan juga merancang lembar validasi sebagai instrument pengumpulan data.

\section{Tatap Pengembangan}

Pengembangan media pembelajaran berbasis android ini menggunakan software smart apps cerator (SAC) dengan mengacu pada storyboard yang telah dibuat pada tahap sebelumnya. Media pembelajaran yang dihasilkan dengan menggunkaan software SAC ini berbentuk aplikasi yang dapat digunakan pada smartphone yang bersistem android.

Dalam media pembelajaran ini terdapat beberapa tampilan media yaitu tampilan awal media, tampilan isi media dan tampilan akhir media. Pada tampilan awal media terdiri dari halamanan startpage, halaman judul media, halaman menu, halaman KI dan KD, halaman tujuan pembelajaran dan halaman menu materi. Tampilan awal media dapat dilihat pada gambar berikut.
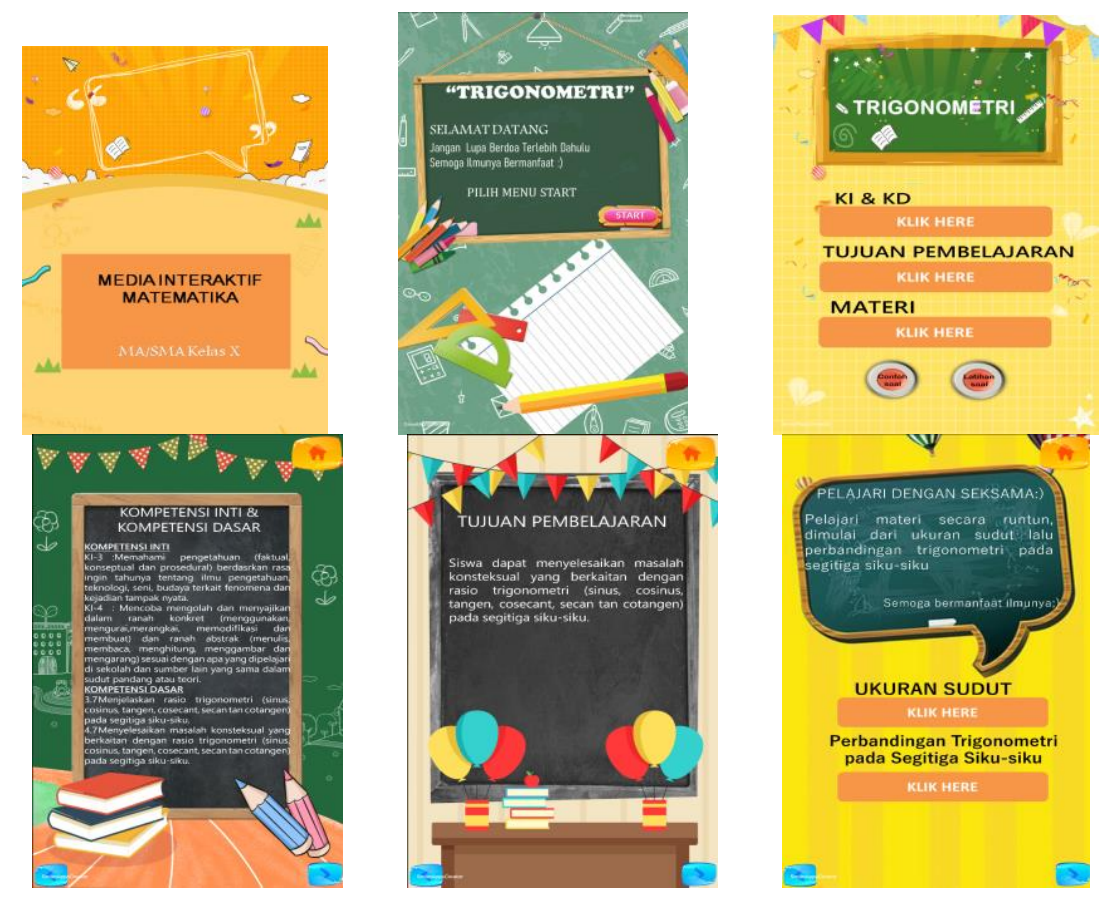

Gambar 1. Tampilan awal media

Tampilan berikutnya pada media ini yaitu tampilan isi. Tampilan ini merupakan materi yang akan dibahas yaitu ukuran sudut dan perbandingan trigonometri pada segitiga siku-siku serta dilengkapi dengan contoh soal. Tampilan dapat dilihat pada gambar berikut. 


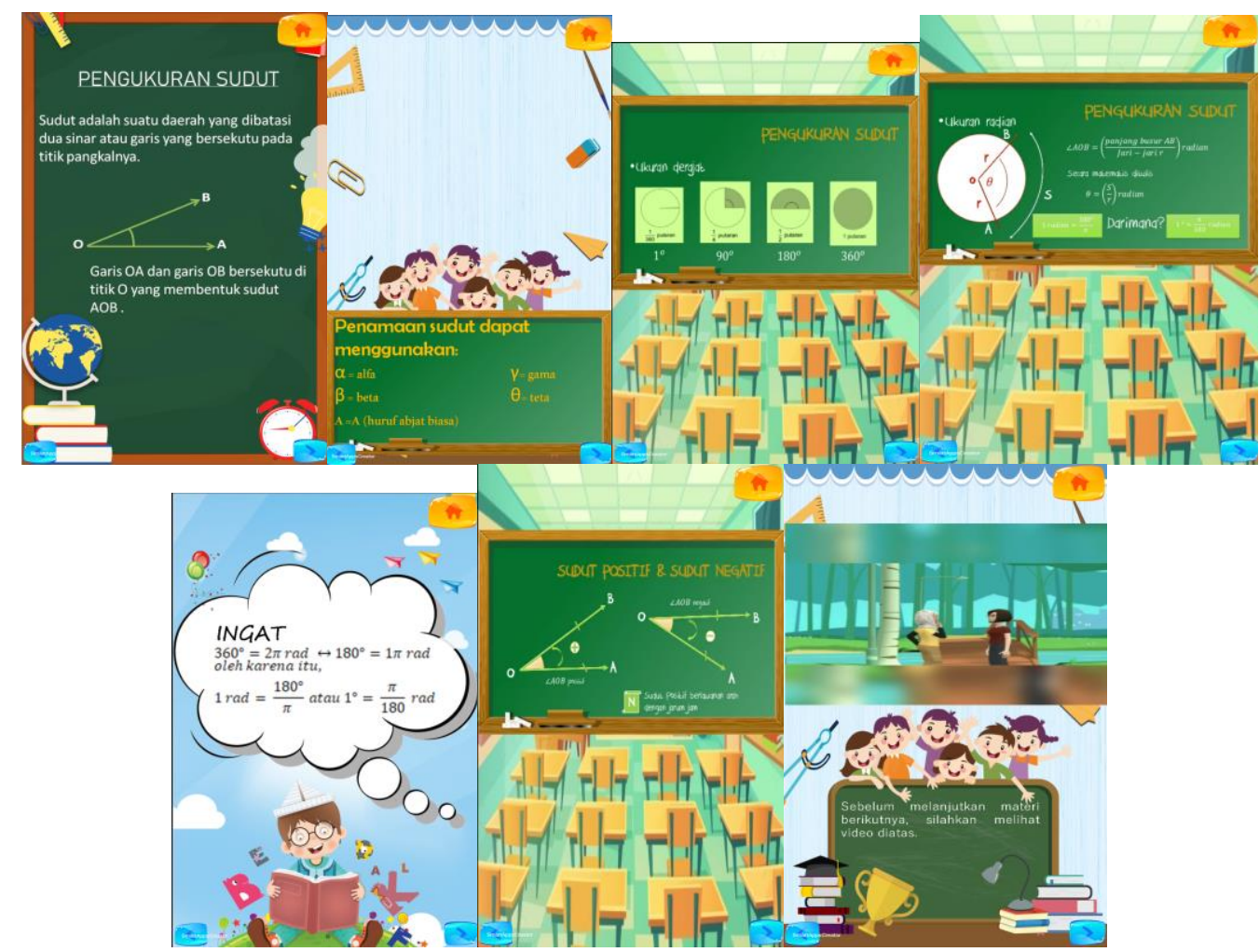

Gambar 2. Tampilan materi ukuran sudut

Gambar 2 merupakan tampilan materi ukuran sudut. Dalam materi ini menjelaskan tentang pengertian sudut, ukuran sudut derajat dan radian, penamaan sudut, arah sudut dan video tentang permasalahan kontekstual yang berkaitan dengan perbandingan trigonometri yang akan dibahas pada secen contoh soal.

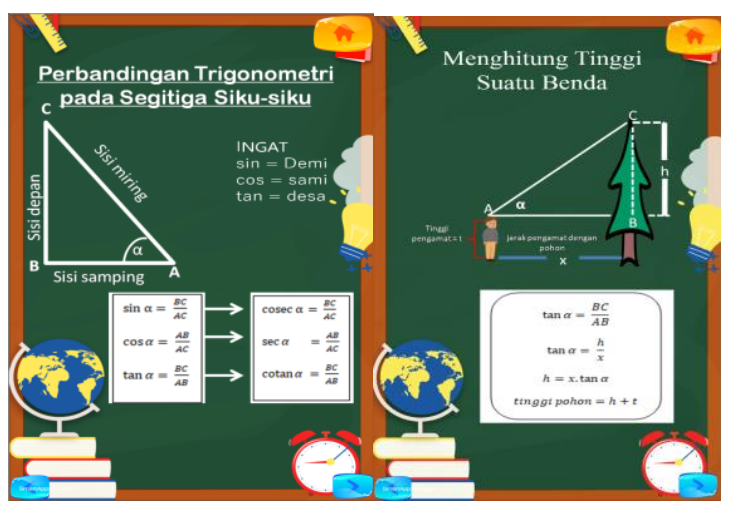

Gambar 3. Tampilan materi perbandingan trigonometri pada segitiga siku-siku

Gambar 3 merupakan penjelasan tentang sub materi perbandingan trigonometri pada segitiga siku-siku dan materi cara mengitung tinggi suatu pohon. 


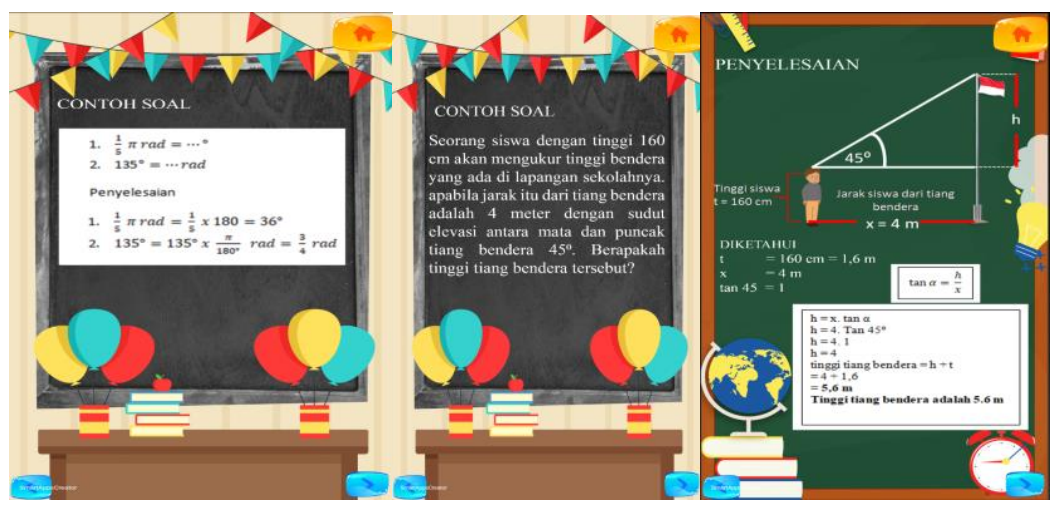

Gambar 4. Contoh soal

Pada tampilan akhir ini berisi latihan soal untuk siswa. Setiap jawaban yang benar maka skor akan bertambar 10 poin dan jika salah maka skor akan bertambar 0. Di akhir media ini akan ditampilkan hasil skor total yang diperolah siswa. Tampilan dapat dilihat pada gambar berikut.
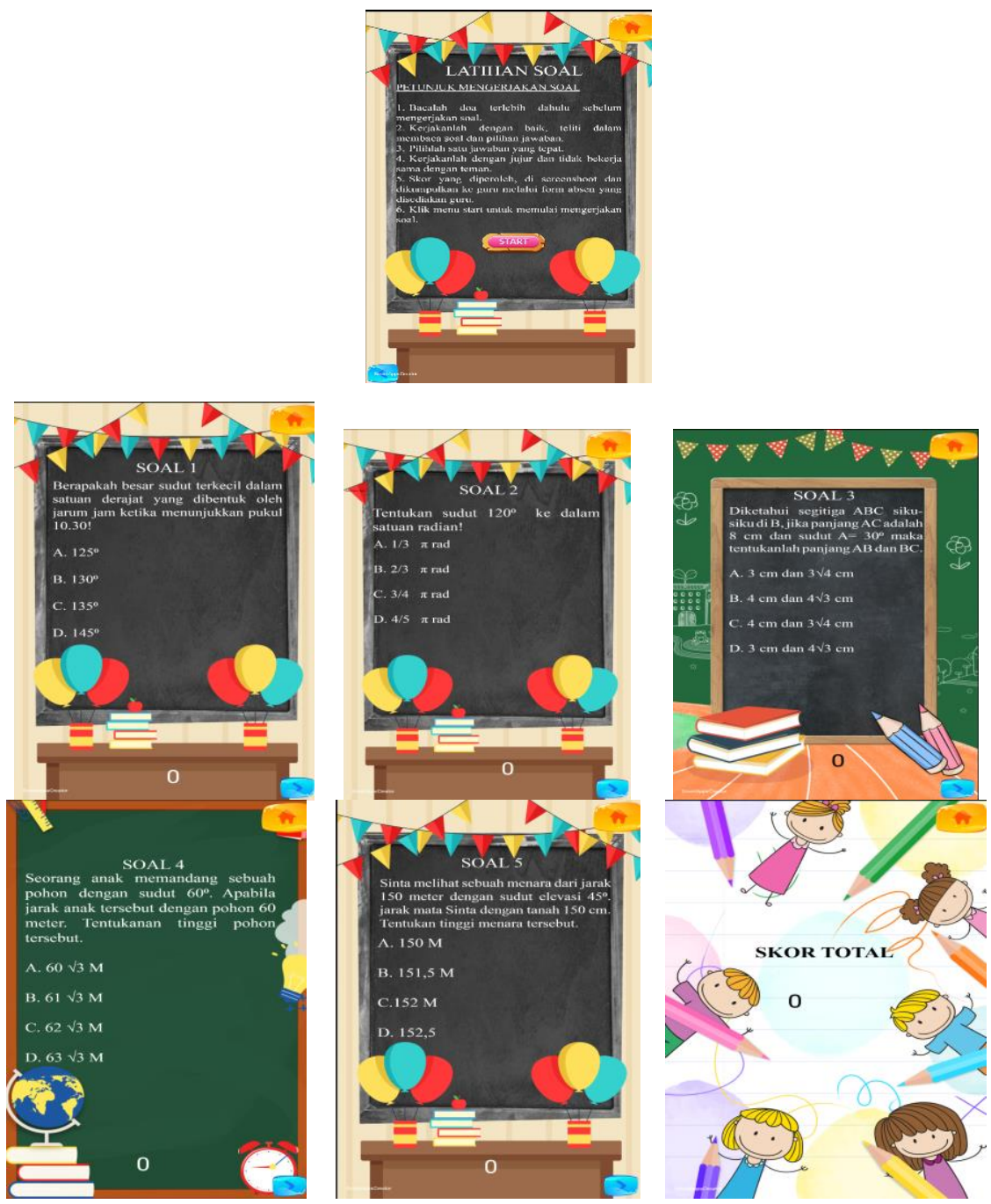

Gambar 5. Latihan soal dan skor total 
Setelah media selesai dikembangkan, pada tahap selanjutnya dilakukan uji validasi untuk menyatakan kelayakan dari media yang telah dikembangkan sebelumnya sebelum media tersebut diuji cobakan kepada siswa. Hasil analisis lembar validasi menunjukkan bahwa media pembelajaran berbasis android dinyatakan valid dengan presentase skor ahli media yaitu $80,88 \%$ dan presentase ahli materi yaitu $75 \%$, peneliti juga mendapatkan saran dan komentar dari para validator yang ditampilkan pada tabel berikut.

Tabel 4. Saran dan tindak lanjut

\begin{tabular}{|c|c|}
\hline Saran dan komentar & Tindak Lanjut \\
\hline \multicolumn{2}{|l|}{ Ahli media } \\
\hline $\begin{array}{l}\text { 1. Perbaikan kualitas gambar video } \\
\text { 2. Menghilangkan tombol home pada } \\
\text { tampilan latihan soal } \\
\text { 3. Memberikan tombol ulangi pada akhir } \\
\text { latihan soal }\end{array}$ & $\begin{array}{l}\text { 1. Peneliti memperbaiki kualitas dari } \\
\text { gambar yang ada pada video } \\
\text { 2. Peneliti menghapus tombol home pada } \\
\text { tampilan latihan soal } \\
\text { 3. Peneliti memberikan tombol ulangi } \\
\text { pada akhir latihan soal }\end{array}$ \\
\hline \multicolumn{2}{|l|}{ Ahli materi } \\
\hline $\begin{array}{l}\text { 1. Memberikan penjelasan pada bagian } \\
\text { "ingat" }\end{array}$ & $\begin{array}{l}\text { 1. Peneliti memberikan penjelasan } 1 \text { pada } \\
\text { bagian "ingat" }\end{array}$ \\
\hline $\begin{array}{l}\text { 2. Kesalahan penulisan rumus pada } \\
\text { materi perbandingan trigonometri } \\
\text { 3. Agar diberikan batas waktu dalam } \\
\text { penegerjaan soal }\end{array}$ & $\begin{array}{l}\text { 2. Peneliti memperbaiki kembali } \\
\text { penulisan rumus pada materi } \\
\text { perbandingan trigonometri } \\
\text { 3. Peneliti memberikan waktu dalam } \\
\text { pengerjaan soal yaitu } 5 \text { menit dalam } 1 \\
\text { soal }\end{array}$ \\
\hline
\end{tabular}

Dari analisis lembar validasi tersebut menyatakan bahwa media pembelajaran berbasis android dinyatakan valid untuk digunakan dengan perbaikan sebelum media tersebut diuji cobakan sesuai dengan saran dan komentar yang diberikan oleh para validator.

\section{Tahap Implmentation}

Setelah media dinyatakan valid oleh para validator kemudia tahap selanjutnya yaitu tahap uji coba. Uji coba ini dilakukan kepada siswa kelas X MA Miftahul Ulum berjumlah 27 siswa. Setelah siswa menggunakan media pembelajaran tesebut, siswa memberikan respon dengan mengisi angket respon untuk mengetahui kepraktisan dari media pembelajaran yang telah dibuat.

\section{Tahap Evalution}

Tahap ini merupakan tahap dimana angket respon siswa dianalisis guna mengurangi kelemahan media yang dikembangkan. Dalam merevisi media ini tidak lepas dari saran dan komentar dari para validator sebelumnya agar tidak bertentangan. Dan dalam penelitian ini, saran yang diberikan siswa tidak bertentangan dengan validator. Hasil analisis angket respon siswa dapat dilihat pada tabel berikut 
Tabel 4. Analisis Angket Respon Siswa

\begin{tabular}{|c|c|c|c|c|c|c|c|c|c|c|}
\hline \multirow{2}{*}{ RESPONDEN } & \multicolumn{10}{|c|}{ PERNYATAAN } \\
\cline { 2 - 10 } & $\mathbf{1}$ & $\mathbf{2}$ & $\mathbf{3}$ & $\mathbf{4}$ & $\mathbf{5}$ & $\mathbf{6}$ & $\mathbf{7}$ & $\mathbf{8}$ & $\mathbf{9}$ & $\mathbf{1 0}$ \\
\hline 1 & 3 & 3 & 3 & 3 & 3 & 3 & 3 & 2 & 3 & 3 \\
\hline 2 & 3 & 3 & 1 & 3 & 4 & 4 & 4 & 4 & 1 & 1 \\
\hline 3 & 2 & 3 & 3 & 3 & 3 & 3 & 3 & 3 & 3 & 4 \\
\hline 4 & 3 & 3 & 3 & 2 & 3 & 4 & 3 & 3 & 4 & 4 \\
\hline 5 & 4 & 2 & 4 & 3 & 3 & 4 & 3 & 3 & 3 & 3 \\
\hline 6 & 4 & 3 & 3 & 2 & 3 & 3 & 3 & 3 & 3 & 4 \\
\hline 7 & 3 & 3 & 3 & 3 & 4 & 4 & 4 & 4 & 3 & 3 \\
\hline 8 & 3 & 3 & 3 & 3 & 4 & 4 & 4 & 4 & 3 & 3 \\
\hline 9 & 3 & 3 & 3 & 3 & 3 & 4 & 3 & 2 & 2 & 3 \\
\hline 10 & 4 & 2 & 3 & 3 & 3 & 3 & 2 & 2 & 3 & 4 \\
\hline 11 & 4 & 4 & 4 & 4 & 2 & 3 & 3 & 3 & 2 & 2 \\
\hline 12 & 4 & 3 & 3 & 3 & 2 & 2 & 4 & 3 & 3 & 3 \\
\hline 13 & 3 & 3 & 3 & 3 & 3 & 3 & 3 & 3 & 3 & 3 \\
\hline 14 & 3 & 3 & 3 & 3 & 3 & 3 & 3 & 3 & 3 & 3 \\
\hline 15 & 4 & 4 & 4 & 4 & 2 & 3 & 2 & 3 & 3 & 3 \\
\hline 16 & 3 & 3 & 3 & 3 & 3 & 3 & 3 & 3 & 3 & 3 \\
\hline 17 & 3 & 3 & 3 & 3 & 4 & 3 & 3 & 3 & 3 & 3 \\
\hline 18 & 3 & 4 & 3 & 3 & 3 & 4 & 4 & 4 & 2 & 3 \\
\hline 19 & 3 & 3 & 3 & 4 & 4 & 3 & 3 & 4 & 4 & 4 \\
\hline 20 & 3 & 3 & 4 & 4 & 3 & 4 & 2 & 4 & 4 & 4 \\
\hline 21 & 3 & 3 & 3 & 3 & 3 & 3 & 3 & 3 & 3 & 3 \\
\hline 22 & 2 & 3 & 2 & 2 & 3 & 2 & 2 & 2 & 3 & 3 \\
\hline 23 & 2 & 2 & 2 & 2 & 2 & 3 & 3 & 3 & 3 & 3 \\
\hline 24 & 3 & 4 & 3 & 2 & 2 & 2 & 2 & 2 & 3 & 3 \\
\hline 25 & 3 & 4 & 2 & 2 & 2 & 2 & 2 & 3 & 2 & 2 \\
\hline 26 & 2 & 2 & 4 & 2 & 2 & 2 & 3 & 4 & 2 & 3 \\
\hline 27 & 2 & 2 & 3 & 4 & 3 & 2 & 3 & 2 & 2 & 3 \\
\hline Skotal skoritem & 82 & 81 & 81 & 79 & 79 & 83 & 80 & 82 & 76 & 83 \\
\hline 20,5 & 20,25 & 20,25 & 19,75 & 19,75 & 20,75 & 20 & 20,5 & 19 & 20,75 \\
\hline & & & & & 74,63 & & & & \\
\hline
\end{tabular}

\section{Diskusi}

Pengembangan media pembelajaran matematika berbasis android ini menggunakan model pengembangan ADDIE yaitu analisys, design, development, implementation and evalution. Pada tahap analisys, peneliti menemukan suatu permasalahan yang dihadapi siswa di MA Miftahul ulum terkait kebutuhan akan media pembelajaran. Kemudian pada tahap design, peneliti merancang materi yang akan digunakan pada media pembelajaran, storyboard media dan instrument penelitian yang akan digunakan. Pada tahap development, peneliti mengembangkan storyboard yang dibuat sebelumnya menjadi suatu media pembelajaran dengan menggunakan software smart apps creator. Dalam pengembangan media ini terdapat scene pada storyboard media yaitu scene yang terdapat tombol keluar atau exit yang tidak dapat dibuat oleh peneliti karena dalam software smart apps creator tidak ada menu pembuatan tombol keluar atau exit. setelah media pembelajaran telah selesai dibuat kemudian dilakukan uji validasi untuk mengetahui apakah media yang telah dibuat dinyatakan valid oleh para validator dan dalam uji validasi ini menunjukan bahwasanya media pembelajaran dinyatakan valid dengan rata-rata presentase skor $77,94 \%$. Pada tahap implemtation yaitu setelah media 
pembelajaran dinyatakan valid kemudian dapat dilakukan uji coba. Uji coba dalam penelitian ini dilakukan di MA miftahul ulum yang terdiri dari 27 siswa. Setelah siswa menggunakan media pembelajaran, siswa memberikan tanggapan terkait media pembelajaran yang dikembangkan dengan cara mengisi angket respon siswa yang diberikan oleh peneliti. Pada tahap selanjutnya yaitu tahap analisis, pada tahap ini peneliti menganalisis hasil angket respon siswa untuk mengurangi kelemahan media pembelajaran yang dikembangkan dan untuk mengetahui kepraktisan media pembelajaran tersebut.

\section{Simpulan}

Dalam pengembangan media pembelajaran berbasis android ini peneliti menggunakan model pengembangan ADDIE dengan 5 tahapan yaitu analysis, design, development, implementation, evaluation. Media pembelajaran matematika berbasis android ini dinyatakan valid oleh para para validator dengan presentase skor ahli media yaitu 80,88\% dan presentase skor ahli materi yaitu 75\% dengan rata-rata presentase yang didapat yaitu 77,97\% sehingga media yang dikembangkan ini dapat diuji cobakan. Sedangkan hasil analisis angket respon siswa yaitu 74,63\% sehingga media ini praktis untuk digunakan.

\section{Konflik Kepentingan}

Penulis menyatakan tidak ada konflik kepentingan

\section{Referensi}

Anggriani, A. D., Kusumayanti, A., \& Nur, F. (2020). PengembangaAnggriani, Andi Dian, Andi Kusumayanti, and Fitriani Nur. 2020. "Pengembangan Media Pembelajaran MathSC Berbasis Android Menggunakan App Inventor 2 Pada Materi Barisan Dan Deret Aritmatika." Jurnal Cendekia: Jurnal Pendidikan Matematika 4 (2): Jurnal Cendekia: Jurnal Pendidikan Matematika, 4(2), 926-938. https://doi.org/10.31004/cendekia.v4i2.322

Auliya, R. N. (2016). Kecemasan Matematika dan Pemahaman Matematis. Formatif: Jurnal Ilmiah Pendidikan MIPA, 6(1), 12-22. https://doi.org/10.30998/formatif.v6i1.748

Barokati, N., \& Annas, F. (2013). Pengembangan Pembelajaran Berbasis Blended Learning pada Mata Kuliah Pemrograman Komputer (Studi Kasus: UNISDA Lamongan). Sisfo, 4(5), 352-359. https://doi.org/10.24089/j.sisfo.2013.09.006

Hamzah B. Uno. (2010). Model pembelajaran: menciptakan proses belajar mengajar yang kreatif dan efektif. In Jakarta: Bumi Aksara. Bumi Aksara.

Nurkholis. (2013). Pendidikan dalam Upaya Memajukan Teknologi. Jurnal Kependidikan, $1(1), 24-44$.

Nurrita, T. (2018). Pengembangan media pembelajaran untuk meningkatkan hasil belajar siswa. MISYKAT: Jurnal Ilmu-Ilmu Al-Quran, Hadist, Syariah Dan Tarbiyah, 3(1), 171-210. Media Pembelajaran dan Hasil Belajar Siswa

Prasetyo, Y. D., Yektyastuti, R., Solihah, M., Ikhsan, J., \& Sugiyarto, K. H. (2015). Pengaruh Penggunaan Media Pembelajaran Kimia Berbasis Android Terhadap Peningkatan Motivasi. Prosiding Seminar Nasional Pendidikan Sains (SNPS), November, 252-258. 
Pribadi, B. A. (2016). Desain dan Pengembangan Program Pelatihan Berbasis Kompetensi Implementasi ... - Benny A Pribadi - Google Books. In Kencana. Prenada Media Group. https://books.google.co.id/books?hl=id\&lr=\&id=m_pDDwAAQBAJ\&oi=fnd\&pg=PA1 $\& \mathrm{dq}=$ model+pengembangan+addie \&ots=y3nYF1x5Au\&sig=WiohwD5ysxI0Vydnf9GL pyALljE\&redir_esc $=\mathrm{y} \# \mathrm{v}=$ onepage $\& \mathrm{q}=$ model pengembangan addie $\& \mathrm{f}=\mathrm{false}$

Sugiyono. (2017). Metode Penelitian Kuantitatif, Kualitatif, dan R\&D. In Alfabeta. Alfabeta. http://scholar.google.com/scholar?hl=en\&btnG=Search\&q=intitle:Critical+Success+Fact ors + in + the + Performance + of + Female-

+ Owned+Businesses+:+A+Study+of+Female+Entrepreneurs+in+Korea\#2

Suharmi, A. (2010). Prosedur penelitian suatu pendekatan praktik. In R. Cipta (Ed.), Jakarta: Rineka Cipta (13th ed.). Rineka Cipta. http://r2kn.litbang.kemkes.go.id:8080/handle/123456789/62880

Supardi, S. U. S. (2015). Hasil Belajar Matematika Siswa Ditinjau dari Interaksi Tes Formatif Uraian dan Kecerdasan Emosional. Formatif: Jurnal Ilmiah Pendidikan MIPA, 3(2), 7896. https://doi.org/10.30998/formatif.v3i2.115

Tegeh, I. M., \& Kirna, I. M. (2013). Pengembangan Bahan Ajar Metode Penelitian Pendidikan dengan ADDIE Model. Jurnal IKA, 11 . https://ejournal.undiksha.ac.id/index.php/IKA/article/view/1145

Zainal Arifin. (2010). Metode Penelitian Pendidikan Filosofi, Teori dan Aplikaisnya (L. Cendekia (ed.)). Lentera Cendekia. 